\title{
PENGEMBANGAN MODEL MODUL IPA \\ BERBASIS PROBLEM SOLVING METHOD \\ BERDASARKAN KARAKTERISTIK SISWA DALAM PEMBELAJARAN \\ DI SMP/MTs
}

\author{
Izaak H. Wenno \\ FKIP Universitas Pattimura Ambon (e-mail:wennoiz@yahoo.co.id; \\ HP 081343018564)
}

\begin{abstract}
Developing Science Module Models Based on the Problem Solving Method on the Basis of Students' Learning Characteristics in SMP/MTs. This study aims to investigate the learning process in the laboratory using modules based on the problem solving method, effects of the module models on the students' achievement, the effectiveness of the modules, and the evaluation system in the modules. This study was a research and development study employing a model by Borg and Gall. The research subjects comprised students, teachers, and principals. The data were collected through observations and interviews and analyzed using the descriptive technique. The results show that the module models, namely experiment and non-experiment student work sheets based on the problem solving method, and the evaluation system in science learning can be used as an alternative.
\end{abstract}

Keywords : science module models, problem solving method, and science teaching

\section{PENDAHULUAN}

Salah satu permasalahan pendidikan yang dihadapi bangsa Indonesia adalah rendahnya mutu pendidikan. Walaupun berbagai upaya sudah dilakukan, namun hingga kini mutu pendidikan belum menunjukkan peningkatan yang berarti baik pada jenjang pendidikan dasar dan menengah, maupun pada jenjang pendidikan tinggi. Dalam penyelenggaraan pendidikan, perhatian terhadap makna belajar dan pencapaiannya menjadi sangat penting dan berarti dalam pengembangan pendidikan di masa datang. Untuk mengatasi masalah ini banyak hal yang harus dilaku- kan demi untuk peningkatan mutu pendidikan, hal yang terpenting adalah terletak pada proses belajar mengajar di dalam kelas yang melibatkan pendidik dan peserta didik karena proses belajar mengajar yang terjadi di sekolah merupakan suatu kegiatan yang dilakukan di kelas yang tidak hanya berpatokan pada penguasaan prinsip-prinsip yang fundamental,melainkan juga mengembangkan sikap yang positif terhadap belajar, penelitian, dan penemuan serta pemecahan masalah.

Permasalahan pembelajaran sains (termasuk fisika, biologi, dan kimia) antara lain berhubungan dengan tiga hal, 
yaitu kreativitas, bahan ajar bahan kajian, dan keterampilan proses sains. Dalam proses pembelajaran di sekolah saat ini guru belum memberi kesempatan yang optimal kepada siswa untuk dapat mengembangkan kreativitasnya. Hal ini terjadi karena beberapa hal, antara lain: (1) gaya mengajar guru sains yang selalu menyuruh siswa untuk menghafal berbagai konsep tanpa disertai pemahaman terhadap konsep tersebut; (2) pengajaran sains umumnya banyak dilakukan dengan cara menghafal dan sangat minim dengan kerja laboratorium; (3) masih banyak guru sains yang berpendapat bahwa mengajar itu suatu kegiatan menjelaskan dan menyampaikan informasi tentang konsep-konsep; (4) soal-soal ujian semester dan akhir kurang memotivasi siswa berpikir kreatif, karena soal-soal yang diajukan hanya dititik beratkan pada aspek kognitif yang umumnya berbentuk pilihan ganda, dan (5) fasilitas sekolah untuk menopang siswa mengembangkan kreativitasnya, terutama yang berkaitan dengan perkembangan sains teknologi umumnya kurang memadai.

Menyadari betapa pentingnya pendidikan sains, telah banyak dilakukan upaya peningkatan kualitas pembelajaran sains di sekolah. Upaya ini dapat dilihat antara lain dari langkah penyempurnaan kurikulum yang terus dilakukan, peningkatan kualitas guru bidang studi, penyediaan dan pembaruan buku ajar, penyediaan dan perlengkapan alatalat pelajaran (laboratorium) sains. Namun demikian, sampai sejauh ini pencapaian hasil belajar sains di sekolah secara umum dapat dinyatakan masih belum sesuai dengan harapan.
Sains atau Ilmu Pengetahuan Alam adalah ilmu yang pokok bahasannya adalah alam dengan segala isinya. Hal yang dipelajari dalam sains adalah sebab-akibat, hubungan kausal dari kejadian-kejadian yang terjadi di alam. Menurut Powler (Winataputra, 1993: 23), sains adalah ilmu yang sistematis dan dirumuskan dengan mengamati gejala-gejala kebendaan, dan didasarkan terutama atas pengamatan induksi. Carin dan Sund (1990:4) menyatakan bahwa: science is the system of knowing about the universe through data collected by observation and controlled eksperimentation. As data are collected, theries are advanced to explain and account for what has been observed.

Sains sebagai pengetahuan yang sistematis atau tersusun secara teratur, berlaku umum, dan berupa kumpulan data hasil observasi dan eksperimen. Cara menguji teori dalam sains, ada tiga cara, yaitu kemampuan untuk menjelaskan apa yang diobservasi, kemampuan untuk memprediksi apa yang belum diobservasi dan kemampuannya untuk menguji melalui eksperimen, dan untuk memodifikasi data-data yang diperlukan. Aktivitas dalam sains selalu berhubungan dengan percobaan-percobaan yang membutuhkan keterampilan dan ketekunan. Secara sederhana, sains dapat juga didefinisikan sebagai apa yang dilakukan oleh para ahli sains. Dengan demikian, sains bukan hanya kumpulan pengetahuan tentang benda atau makhluk hidup, tetapi menyangkut cara kerja, cara berpikir, dan cara memecahkan masalah. Ilmuwan sains selalu tertarik dan memperhatikan peristiwa alam, selalu ingin mengetahui 
apa, bagaimana, dan mengapa tentang suatu gejala alam dan hubungan kausalnya.

Carin and Sund (1990: 2), dalam buku Teaching Modern Science, menyatakan:

"... Science is a human activity that has evolved as an intellectual tool to facilate describing and ordering the environment. Once one accepts the idea that science does not exist in any other realm but the mind, it ceases to be "thing", an entity with its own existence. Though scientific truth or fact is ideally objective, it is subject to human perception and logic......As a method, science is relatively stable and universally spplied, while as body knowledge, it is constantly changing.

Sains adalah aktivitas manusia yang meliputi, cara-cara intelektual sebagai fasilitas untuk deskripsi dan pemahaman mengenai lingkungan. Sebagai suatu metode sains adalah sesuatu yang relatif stabil yang dapat diaplikasikan secara universal sebagai suatu body of knowledge dan perubahannya konstan. Selanjutnya, Carin and Sund (1990) menyatakan bahwa sains adalah scientific attitudes: yakni keyakinan, nilai-nilai, pendapat/gagasan, dan objektif, misalnya: keputusan setelah memperoleh data yang berkaitan dengan permasalahan selalu berusaha untuk bersikap objektif, jujur, dan lain-lain. Scientific processes scientific methods adalah cara khusus dalam penyelidikan untuk memecahkan suatu masalah, misalnya membuat hipotesis, merangsang dan melaksanakna eksperimen, mengumpulkan dan menyusun data, mengevaluasi data, mengukur dan sebagainya. Scientific products (produk ilmiah) adalah berupa fakta, prinsip, hukum, teori dan lain-lain. Misalnya, prinsip ilmiah.

Belajar sains dengan menerapkan metode eksperimen, menggunakan modul yang di dalamnya di desain lembar kegiatan siswa (LKS), baik eksperimen maupun non eksperimen, berarti belajar sains dengan menggunakan alat ukur. Keterampilan siswa dalam mengikuti eksperimen turut berpengaruh terhadap hasil dari kegiatan tersebut. Pada saat mengikuti eksperimen sering terjadi alat yang digunakan tidak sesuai dengan apa yang diharapkan, sehingga kevalidan dari alat tersebut tidak akurat. Untuk itu siswa dituntut untuk lebih kreatif dan cermat dalam melihat dan menginterpretasikan serta mengamati kelayakan dari alat tersebut. Modul sains berbasis problem solving method yang dikembangkan dalam penelitian pengembangan ini, yakni bahan yang digunakan untuk membantu guru sains dalam melaksanakan kegiatan belajar mengajar sains, baik di kelas maupun di laboratorium yang isinya menyangkut masalah-masalah sains yang harus dipecahkan oleh siswa secara sistematis dan terarah serta didasarkan pada karakteristik siswa, yakni; sikap, minat dan kemapuan siswa dalam memecahkan masalah sains. Modul sains ini merupakan sebuah buku yang ditulis dengan tujuan agar siswa dapat belajar secara mandiri tanpa atau dengan bimbingan guru sains.

Pembelajaran sains dengan menggunakan bahan ajar modul akan sangat bermanfaat bagi guru sains dalam menyampaikan materi kepada siswa, siswa lebih kreatif dalam mengembangkandirinya, kegiatan pembelajaran men- 
jadi lebih menarik, siswa akan lebih banyak mendapatkan kesempatan untuk belajar secara mandiri, mengurangi ketergantungan terhadap kehadiran guru sains, dan siswa juga akan mendapatkan kemudahan dalam mempelajari setiap kompetensi yang harus dikuasainya.

Sebuah modul akan bermakna, kalau siswa dapat dengan mudah menggunakannya. Pembelajaran dengan modul memungkinkan siswa yang memiliki kecepatan tinggi dalam belajar akan lebih cepat menyelesaikan satu atau lebih kompetensi dasar (KD) dibandingkan dengan siswa lainnya. Dengan demikian, maka modul harus menggambarkan kompetensi dasar (KD) yang akan dicapai oleh siswa, disajikan dengan menggunakan bahasa yang baik, menarik, dan dilengkapi dengan ilustrasi.

Modul sains berbasis problem solving method adalah salah satu jenis bahan ajar yang digunakan untuk membantu guru sains dalam melaksanakan kegiatan belajar mengajar sains, baik di kelas maupun di laboratorium yang isinya menyangkut masalah-masalah sains yang harus dipecahkan oleh siswa secara sistematis dan terarah. Hal ini dimaksudkan agar guru sains dengan mudah menyampaian materi sains kepada siswa dan dapat mendeteksi kompetensi siswa dalam unjuk kerja. Siswa akan lebih mudah belajar sains, karena di dalam modul sains berbasis problem solving method yang dikembangkan ada berbagai masalah-masalah sains yang dapat dikerjakan oleh siswa, baik secara individual maupun secara kelompok.

\section{METODE}

Subjek yang terlibat dalam penelitian ini adalah siswa kelas VII di Wilayah Propinsi Maluku berperan sebagai individu yang akan dikembangkan kemampuan memecahkan masalah sains di SMP/MTs. Guru sains berperan sebagai aktor yang akan melaksanakan rancangan model pembelajaran dan mengevaluasi model modul bersama dengan peneliti secara kolaboratif. dan kepala sekolah berperan sebagai pendukung pelaksanaan model modul sains berbasis problem solving method. Metode penelitian yang digunakan adalah metode penelitian pengembangan, mengikuti model yang dikembangkan oleh Borg \& Gall (1998:775) dengan prosedur penelitian meliputi: (1) survei pendahuluan; (2) perencanaan model yang akan dikembangkan; (3) mengadakan uji coba produk; (4) pengembangan produk; (5) tes validasi; dan (6) sosialisasi dan implementasi hasil penelitian (produk). Berdasarkan langkah-langkah ini, maka prosedur penelitian dibagi menjadi tiga tahapan utama.

Pada tahap pertama terlebih dahulu dilakukan need assessment dengan menganalisis kebutuhan-kebutuhan yang bertujuan seperti berikut.

- Mengidentifikasi pelaksanaan proses pembelajaran di laboratorium saat ini oleh guru sains SMPMTs.

- Mengidentifikasi sarana prasarana (media) yang digunakan dalam proses belajar mengajar sains SMPMTs.

- Mengidentifikasi model pembelajaran di laboratorium yang digunakan saat ini. 
- Mengidentifikasi dampak implementasi model pembelajaran di laboratorium.

- Mengidentifikasi model sistem evaluasi yang digunakan dalam menilai keterampilan (performance) dalam bereksperimen di laboratorium.

Tahap kedua adalah pengembangan darihasil penelitian tahap pertama yang langkah-langkahnya seperti berikut.

- Menyusun panduan pelaksanaan proses pembelajaran di laboratorium saat ini oleh guru sains SMPMTs.

- Menyusun panduan model modul (LKS eksperimen dan LKS non eksperimen berbasis problem solving method).

- Menyusun panduan model sistem evaluasi dalam eksperimen di laboratorium.

- Validasi ketiga produk tersebut di atas dengan melibatkan para ekspert seperti ahli R \& D, belajar dan pembelajaran, dan ahli desain (rancangan), sehingga ketiga produk tersebut memiliki validitas isi (content validity) yang bisa dipertanggung jawabkan.

Tahap ketiga adalah pentahapan dalam melaksanakan uji coba (eksperimen) tentang: (1) panduan pelaksanaan proses pembelajaran di laboratorium saat ini oleh guru sains SMPMTs; (2) panduan model modul (LKS eksperimen dan LKS non ekasperimen berbasis problem solving method); dan (3) panduan model sistem evaluasi dalam eksperimen di laboratorium.

Sumber data dalam penelitian ini adalah data primer (diperoleh dari hasil observasi dan wawancara dengan guru sains, dan siswa SMP MTs pada empat Kabupaten diPropinsi Maluku), sedang- kan teknik pengumpulan data yang digunakan adalah melalui observasi dan wawancara.

Instrumen untuk pengumpulan data meliputi; angket, lembar pengamatan dantes. Angket digunakan untuk mengungkap data tentang kualitas mengajar guru sains, sikap siswa terhadap proses pembelajaran sains dengan menggunakan laboratorium dan fasilitas pelaksanaan proses pembelajaran di kelas dan di laboratorium. Lembar pengamatan digunakanuntuk mengungkap data tentang proses pembelajaran dan aktivitas siswa di kelas dan di laboratorium. Panduan wawancara digunakan untuk mengungkap data tentang sistem evaluasi pembelajaran sains di laboratorium dan kelas. Data yang diperoleh dianalisis secara deskriptif kuantitatif, dengan maksud untuk mengetahui kecenderungan dari tiap-tiap variabel penelitian.

\section{HASIL PENELITIAN TAHAP I}

Diskripsi data hasil penelitian di empat Kabupaten Kota di Propinsi Maluku dapat dijelaskan di bawah ini.

Pelaksanaan Proses Pembelajaran di Laboratorium oleh Guru Sains SMP/ MTs

Dalam proses pembelajaran di SMP/ MTs di Propinsi Maluku saat ini guru sains belum memberi kesempatan yang optimal kepada siswa untuk dapat mengembangkan kreativitasnya. Hal ini terjadi karena beberapa hal antara lain: (1) gaya mengajar guru sains yang selalu menyuruh siswa untuk menghafal berbagai konsep tanpa disertai pemahaman terhadap konsep tersebut; (2) 
pengajaran sains umumnya banyak dilakukan dengan cara menghafal dan sangat minim dengan kerja laboratorium; (3) masih banyak guru sains yang berpendapat bahwa mengajar itu suatu kegiatan menjelaskan dan menyampaikan informasi tentang konsep-konsep; (4) soal-soal ujian semester dan akhir kurang memotivasi siswa berpikir kreatif, karena soal-soal sains yang diajukan hanya dititik beratkan pada aspek kognitif yang umumnya berbentuk pilihan ganda; dan (5) fasilitas sekolah untuk menopang siswa mengembangkan kreativitasnya, terutama yang berkaitan dengan perkembangan sains teknologi umumnya kurang memadai.

Hal lain yang dapat teridentifikasi dalam proses pembelajaran sains di SMP/MTs di Propinsi Maluku, yakni guru sains tidak dapat membangkitkan semangat siswa untuk bertanya, menemukan jawaban dan mengkonstruksi setiap permasalahan sains yang dihadapinya melalui dugaan (prediksi), observasi (pengamatan), eksperimen (melakukan percobaan) dan interpretasi (penjelasan/tanggapan/deskripsi apa yang diprediksi, diobservasi dan dalam melakukan eksperimen di laboratorium atau saat demonstrasi di kelas).

Sarana Prasarana (Media) yang Digunakan dalam Proses Belajar Mengajar Sains SMP/MTs

Dari hasil need assesment terhadap empat Kabupaten di Propinsi Maluku, dapat dikatakan bahwa kurangnya fasilitas dalam menunjang pembelajaran siswa dalam menambah pengetahuan siswa, melalui ketidaktersediaannya laboratorium sains sangat mempengaruhi di mana kegiatan praktek yang mestinya dilakukan oleh siswa untuk menunjang teori yang sudah didapatkan, tidak dapat dilaksanakan.

Dari hasil observasi terhadap proses pembelajaran sains di kelas dan laboratorium dalam penggunaan laboratorium, guru sains tidak kreatif ketika tidak memiliki media, sehingga proses pembelajaran yang semestinya menggunakan media (laboratorium) tidak dapat dilaksanakan guru sains hanya menjelaskan teori dalam bentuk ceramah.

\section{Model, Pendekatan dan Metode Pem- belajaran Sains di Kelas dan Labora- torium yang Digunakan}

Dari hasil analisis kualitatif terhadap observasi yang dilakukan oleh Tim Peneliti terlihat bahwa berbagai strategi pembelajaran sains yang diterapkan dalam menjelaskan materi pelajaran kepada siswa sifatnya monoton, tidak variatif dan kolaboratif. Akibat dari penerapan pembelajaran dengan menggunakan metode, pendekatan dan model pembelajaran seperti ini akan memberikan dampak negatif dalam peningkatan kemampuan berpikir siswa.

Namun, hal yang terpenting dalam pembelajaran sains, yakni menjadikan pembelajaran sains yang humanis (manusiawi), di mana siswa ditempatkan atau dipandang sebagai subjek, bukan sebagai objek. Sebagai subjek siswa adalah pribadi dinamis yang sedang berjuang mengembangkan diri untuk menjadi lebih manusiawi, lebih sempurna dalam seluruh aspek kemanusiaannya antara lain pengetahuan, kemampuan, keterampilan, sikap, dan perasaannya. Jadi, pembelajaran sains harus 
ditafsirkan sebagai penciptaan situasi, kemudahan, pemberian bimbingan agar mereka membentuk dan mengembangkan dirinya secara optimal melalui serangkaian proses yang mereka alami.

\section{Dampak Implementasi Model, Pende- katan dan Metode Pembelajaran Sains di Kelas dan Laboratorium}

Akibat berbagai strategi pembelajaran yang diterapkan tidak didasarkan pada tipe belajar dan karakter dari siswa-siswa SMPATs dalam pembelajaran sains akan memberikan dampak yang negatif bagi siswa dalam mempelajari konsep-konsep sains. Oleh sebab itu, pembelajaran yang baik dan menyenangkan adalah pembelajaran yang memberikan kesempatan kepada siswa untuk menyampaikan ide/gagasan menurut apa yang mereka ketahui. Proses pembelajaran seperti ini akan mengubah paradigma dalam proses pembelajaran sains yang tadinya berpusat pada guru (teacher centered) menjadi pembelajaran yang berpusat pada siswa (learner centered) yang diharapkan dapat mendorong siswa untuk terlibat secara aktif dalam membangun pengetahuan, sikap dan perilaku. Melalui proses pembelajaran dengan keterlibatan aktif siswa ini berarti guru sains tidak mengambil hak siswa untuk belajar dalam arti yang sesungguhnya. Dalam proses pembelajaran sains yang berpusat pada siswa, maka siswa memperoleh kesempatan dan fasilitasi untuk membangun sendiri pengetahuannya, sehingga mereka akan memperoleh pemahaman yang mendalam (deep learning), dan pada akhirnya dapat meningkatkan kualitas prestasi belajar siswa.
Model Sistem Evaluasi yang Digunakan dalam Menilai Keterampilan (Performance) dalam Bereksperimen Sains di Kelas dan Laboratorium

Sistem evaluasi yang digunakan oleh guru sains SMPMTs di Propinsi Maluku selalu menggunakan sistem evaluasi sumatif yang hanya mengandalkan tes akhir dalam satu semester berjalan. Hal ini berakibat pada penampilan siswa dalam bekerja di laboratorium maupun dalam menyampaikan ide/ gagasan di kelas.

Pada umumnya, guru sains memilih bentuk penilaian kelas tanpa banyak mempertimbangkan seperti bagaimana mereka menilai dan apa yang akan dinilai. Guru sains memberi tes khusus pada siswa desesuaikan dengan sekolah, di mana siswa yang memperoleh skor baik akan dinilai baik, dan siswa yang memperoleh skor jelek akan dinilai jelek. Namun, penilaian yang baik adalah penilaian yang mencerminkan karakteristik siswa, dari awal sampai akhir pembelajaran bahkan tugas yang diberikan juga dinilai sebagai aktivitas siswa terhadap mata pelajaran sains, bukan akhir dari proses pembelajaran saja yang akan dinilai.

Penilaian yang baik terhadap siswa dilakukan untuk mengetahui sampai sejauhmana kemajuan yang telah dicapai. Apakah siswa telah memiliki kemampuan seperti yang telah dinyatakan dalam tujuan pembelajaran. Penilaian tidak hanya dilakukan oleh guru, tetapi juga oleh siswa untuk mengevaluasi diri mereka sendiri (self asessment) atau penilaian diri. Hal ini akan mendorong siswa untuk berusaha 
lebih baik lagi dari sebelumnya agar mencapai hasil yang maksimal.

\section{DISKRIPSI DATA HASIL UJI COBA TERBATAS}

Dari hasil uji coba terbatas yang berhubungan dengan prodak yang dihasilkan, yakni; panduan pelaksanaan proses pembelajaran sains, panduan model modul dan panduan sistem evaluasi sains pada 2 sekolah diperoleh hasil, seperti Tabel 1 di bawah ini yang menggambarkan nilai rata-rata, standar deviasi dari variabel-variabel penentu keefektifan model modul pembelajaran sains.

Tabel. 1. Data Hasil Uji Coba Terbatas

\begin{tabular}{cccccccc}
\hline Kegiatan & Variabel & $\mathrm{N}$ & Rata-rata & $\begin{array}{c}\text { Standar } \\
\text { Deviasi }\end{array}$ & $\begin{array}{c}\text { Nilai t } \\
\text { hitung }\end{array}$ & df & t-tabel \\
\hline Uji Coba 1 & Sikap & 23 & 84,46 & 8,100 & 42,12 & 53 & 1,96 \\
Uji Coba 2 & & 32 & $\begin{array}{c}103,85 \\
8,56\end{array}$ & & & \\
Total & & & 96,21 & 12,68 & & & \\
Uji Coba 1 & Minat & 23 & 105,92 & 12,44 & 7,07 & 53 & 1,96 \\
Uji Coba 2 & & 32 & 114,40 & 5,81 & & & \\
Total & & & 111,06 & 9,79 & & & \\
Uji Coba 1 & KMMS & 23 & 15,77 & 2,49 & 2,08 & 53 & 1,96 \\
Uji Coba 2 & & 32 & 16,00 & 1,97 & & & \\
Total & & & 15,91 & 2,16 & & & \\
\hline
\end{tabular}

Sumber: Data Penelitian

Keterangan: variabel sikap terhadap sains, minat belajar siswa dan kemampuan memecahkan masalah sains (KMMS) merupakan variabel pendukung, yakni variabel kriteria penentuan kelayakan dari prodak yang dihasilkan, yakni model modul sains berbasis problem solving method.

Berdasarkan Tabel 1 terlihat bahwa nilai rata-rata uji coba kedua (2) lebih besar dan berbeda secara signifikan dengan nilai uji coba pertama (1), dan dapat digambarkan bahwa variabel sikap siswa terhadap sains pada uji coba pertama (1) memiliki nilai rata-rata 84, 46, standar deviasi 8,10 dan pada uji coba kedua (2) nilai rata-rata-rata 103, 85, dan standar deviasi 8,56. Variabel minat belajar siswa terhadap sains pada uji coba pertama (1) memiliki nilai rata-rata 105,92, dan standar deviasi 12,45, dan pada uji coba kedua (2) nilai rata-rata 114,40, dan standar devasi 5,81. Variabel kemampuan memecahkan masalah sains pada uji coba pertama (1) memiliki nilai rata-rata 15,77 , dan standar devasi 2,49, sedangkan pada uji coba kedua (2) memiliki nilai rata-rata 16,00, dan standar deviasi 1,97.

Berdasarkan hasil uji coba terbatas pada dua (2) sekolah di Propinsi Maluku, maka dapat dikatakan bahwa prodak yang dihasilkan, yakni model modul sains berbasis problem solving method dapat dikategori baik, dan layak digunakan dalam proses pembelajaran sains SMPMTs, baik di kelas maupun di laboratorium. Hal ini dapat digam- 
barkan bahwa sikap, minat dan kemampuan siswa memecahkan masalah sains meningkat pada uji coba terbatas.

Setelah peneliti melakukan uji coba terbatas pada 2 sekolah di Propinsi Maluku, dan dilanjutkan dengan pengujian yang lebih luas pada 4 sekolah, yakni SMP Negeri 1 Kairatu, SMP Negeri 3 Kairatu, SMP Negeri 4 Kairatu, dan SMP Negeri 5 Kairatu Kabupaten Seram Bagian Barat (SBB).

\section{DISKRIPSI DATA UJI COBA LUAS}

Data hasil pengujian model modul pembelajaran sains pada SMP Negeri 1, SMP Negeri 3, dan SMP Negeri 4 Kairatu Kairatu Kabupaten Seram Bagian Barat (SBB) dengan jumlah 100 siswa, ditunjukan pada Tabel 2 di bawah ini. Berdasarkan Tabel 2 terlihat bahwa pengujian dua kali, yaitu uji coba ketiga (3), dan uji coba keempat (4). Model ini dapat dinyatakan efektif apabila nilai uji coba ke-4 lebih besar dari uji coba ke-3.

Tabel 2. Data Uji Coba yang Lebih Luas pada SMP di Provinasi Maluku

\begin{tabular}{cccccccccc}
\hline Kegiatan & Variabel & $\mathrm{N}$ & $\begin{array}{c}\text { Rata-rata } \\
\text { Standar Nilai Min }\end{array}$ & $\begin{array}{c}\text { Nilai } \\
\text { Deviasi }\end{array}$ & $\begin{array}{c}\text { Nilait } \\
\text { hitung }\end{array}$ & df & t-tabel \\
\hline Uji Coba 3 & Sikap & 100 & 90,00 & 9,50 & 89,00 & 102,00 & 56,76 & 98 & 3,00 \\
Uji Coba 4 & & 100 & 100,50 & 7,33 & 92,00, & 145,0 & & & \\
$\quad$ Total & & & & & & & & & \\
Uji Coba 3 & Minat & 100 & 105,49 & 15,42 & 86,00 & 132,0 & 9,23 & 98 & 3,00 \\
Uji Coba 4 & & 100 & 118,93 & 9,97 & 105,00 & 129,0 & & & \\
$\quad$ Total & & & & & & & & & \\
Uji Coba 3 & KMMSF & 100 & 16,86 & 4,85 & 8,00 & 19,00 & 8,89 & 98 & 3,00 \\
Uji Coba 4 & 100 & 19,67 & 4,00 & 10,00 & 25,00 & & & \\
$\quad$ Total & & & & & & & & & \\
\hline
\end{tabular}

Sumber: Data Penelitian

Keterangan: variabel sikap terhadap sains, minat belajar siswa dan kemampuan memecahkan masalah sains (KMMS) merupakan variabel pendukung, yakni variabel kriteria penentuan kelayakan dari prodak yang dihasilkan, yakni model modul sains berbasis problem solving method.

Tabel 2 menunjukan bahwa nilai rata-rata uji coba ke-4 lebih besar, dan berbeda secara signifikan dengan nilai uji coba ke-3 dan dapat digambarkan bahwa variabel sikap pada uji coba ke-3 memiliki nilai rata-rata 90,00, standar deviasi 9,50 dan pada uji coba ke-4 nilai rata-rata-rata 100,50 , dan standar deviasi 7,33 . Variabel minat siswa terhadap sains pada uji coba ke-3 memiliki nilai rata-rata 105,49 , dan standar deviasi 15,42 , dan pada uji coba 4 nilai rata-rata 118,93, dan standar deviasi 9,97. Variabel pemecahan masalah pada uji coba ke-3 memiliki nilai rata-rata 16,86, dan standar deviasi 4,85, sedangkan pada uji coba ke-4 memiliki nilai rata-rata 19,67 dan standar deviasi 10,00.

Berdasarkan hasil uji coba yang lebih luas pada empat (4) sekolah di Propinsi Maluku, maka dapat dikatakan bahwa prodak yang dihasilkan, yakni 
model modul sains berbasis problem solving method dapat dikategori baik, dan layak digunakan dalam proses pembelajaran sains SMPMTs, baik di kelas maupun di laboratorium. Hal ini dapat digambarkan bahwa sikap, minat dan kemampuan siswa memecahkan masalah sains meningkat pada uji coba yang lebih luas.

\section{PEMBAHASAN}

Hasil penelitian menunjukkan bahwa hasil belajar sains siswa dengan menerapkan media pembelajaran sains, yakni modul sains berbasis problem solving method sangat baik, bila dibandingkan dengan menggunakan model pembelajaran yang konvensional. Hal ini disebabkan karena dengan melakukan pembelajaranmenggunakan media pembelajaran, maka kemampuan siswa untuk memahami materi pelajaran sains akan lebih sempurna. Menurut Martin \& Briggs (1986:3) yang menyatakan bahwa media pembelajaran mencakup semua sumber yang diperlukan untuk melakukan komunikasi dengan siswa. Ini bisa berupa perangkat keras, seperti komputer, televisi, proyektor, dan perangkat lunak yang dapat digunakan pada perangkat-perangkat keras. Guru juga menurut Martin dan Briggs termasuk media pembelajaran. Jadi, media pembelajaran menurut mereka adalah komponen strategi penyampaian yang dapat dimuati pesan yang akan disampaikan kepada siswa, apakah itu orang, alat atau bahan. Lebih lanjut, dikatakan bahwa media pembelajaran adalah sarana pembawa pesan yang berasal dari suatu sumber pesan (dapat berupa orang atau benda) kepada penerima pe- san. Dalam proses belajar mengajar, penerima pesan adalah siswa. Pembawa pesan (media) itu berinteraksi dengan siswa melalui indera mereka untuk menerima isi pesan atau isi pelajaran yang berasal dari kurikulum yang disampaikan oleh guru kepada siswa.

Dalam proses pembelajaran sains dengan menggunakan media visual, dalam hal ini modul, maka siswa dapat dibantu oleh guru sains untuk membantu menyampaikan isi atau materi pelajaran sains. Oleh karena media visual berfungsi untuk: (1) mengembangkan kemampuan visual; (2) mengembangkan imajinasi siswa; (3) membantu meningkatkan penguasaan siswa terhadap halhal abstrak atau peristiwa yang tidak mungkin dihadirkan di dalam kelas; dan (4) mengembangkan kreativitas siswa, maka guru sains diharapkan dapat menggunakan dan menerapkannya dalam proses pembelajaran sains, baik di kelas maupun di laboratorium.

Dari hasil penelitian yang diperoleh, dapat dikatakan bahwa pembelajaran sains di SMPMTs Propinsi Maluku dengan menggunakan modul sangat bermanfaat bagi guru sains dalam menyampaikan materi sains kepada siswa. Dengan penerapan modul sains berbasis problem solving method, siswa lebih kreatif dalam mengembangkan dirinya, kegiatan pembelajaran sains menjadi lebih menarik, siswa lebih banyak mendapatkan kesempatan untuk belajar secara mandiri, mengurangi ketergantungan terhadap kehadiran guru sains, dan siswa juga akan mendapatkan kemudahan dalam mempelajari setiap kompetensi sains yang harus dikuasainya. 
Dengan demikian, suatu model modul pembelajaran mungkin efektif untuk materi yang satu, tetapi belum tentu sesuai dan efektif untuk materi yang lainnya. Seperti halnya dalam penelitian ini, ternyata didapatkan bahwa media yang digunakan, yakni modul pembelajaran sains berbasi problem solving method lebih unggul dalam meningkatkan hasil belajar sains siswa.

\section{KESIMPULAN}

Berdasarkan temuan dan analisis sebagaimana telah dibahas pada Bab sebelumnya, maka hasil penelitian ini dapat disimpulkan sebagai berikut.

- Beberapa komponen yang dapat mengukur keberhasilan proses belajar-mengajar sains,yaknivariabel kualitas proses belajar mengajar sains, sikap siswa terhadap sains, minat belajar siswa, dan kemampuan siswa memecahkan masalah sains dan variabel sarana prasarana dapat dikategorikan cukup.

- Sistem evaluasi yang digunakan oleh guru sains masih menggunakan sistem evaluasi sumatif yang mengandalkan bentuk penilaian akhir semester, bukan berdasarkan penilaian pada proses pembelajaran.

- Atas dasar kelemahan strategi mengajar, dan media laboratorium yang diterapkan guru sains, perlu mencoba menerapkan model modul (LKS eksperimen dan LKS non eksperimen berbasis problem solving method), dan sistem evaluasi proses yang mengandalkan asesmen autentik sebagai alternatif untuk meminilisasi kelemahan yang ada pada guru sains SMP/ MTs di Propinsi Maluku.
- Secara umum, dapat disimpulkan bahwa model modul pembelajaran sains berbasis problem solving method, dan sistem evaluasi berdasarkan karakteristik siswa dalam pembelajaran sains dapat dikembangkan lebih lanjut sebagai alternatif pemecahan masalah proses pembelajaran sains SMP MTs di Propinsi Maluku.

\section{SARAN}

Berdasarkan temuan-temuan yang diperoleh, maka dalam rangka tindakan lanjut dari hasil penelitian ini disarankan sebagai berikut.

- Pada mata pelajaran sains sebaiknya guru sains SMPAMTs selalu melakukan evaluasi diri sebagai refleksi tentang strategi mengajar yang diterapkan, sehingga siswa sebagai subjek yang belajar benar-benar dapat terjadi di dalam kelas dan laboratorium.

- Model LKS eksperimen dan LKS non eksperimen perlu dikembangkan sebagai alternatif dalam pengembangan modul sains yang dapat membantu guru sains dalam menjelaskan materi kepada siswa.

- Pembelajaran sains yang ada di kurikulum sekolah perlu dikembangkan lebih lanjut dalam berbagai model, media, metode dan pendekatan pembelajaran yang dapat mengembangkan pembelajaran yang demokratis dan humanis.

- Guru sains perlu lebih banyak mengembangkan kegiatan pembelajaran di laboratorium bahkan di luar kelas, karena respons siswa akan lebih positif jika proses pembelajaran bervariasi (tidak hanya dilakukan di dalam kelas). 
- Guru sains lebih banyak mengembangkan kegiatan pembelajaran dengan memberi tugas secara kelompok dalam eksperimen yang membuat siswa aktif mengerjakannya, dan dapat menerapkan penilaian-penilaian alternatif dalam menilai proses belajar siswa, baik dikelas maupun dalam kegiatan-kegiatan eksperimen di laboratorium.

\section{UCAPAN TERIMA KASIH}

Penelitian ini merupakan penelitian Hibah Bersaing yang dibiayai oleh $\mathrm{DP}_{2} \mathrm{M}$ Dirjen Dikti Kementerian Pendidikan Nasional. Oleh sebab itu peneliti mengucapkan terimah kasih kepada $\mathrm{DP}_{2} \mathrm{M}$ Dirjen Dikti yang telah memberikan dana, dan kesempatan kepada peneliti untuk melakukan penelitian di SMP MTs Propinsi Maluku. Ucapan terima kasih juga disampaiakn kepada Kepala Dinas Pendidikan dan Olahraga Kota Ambon, dan Kabupaten Seram Bagian Barat (SBB), Kepala SMP Negeri 1, 3, 4, 5 Kairatu dan MTs Waimital yang memberikan izin dan dukungan kepada peneliti untuk melakukan penelitian.

\section{DAFTAR PUSTAKA}

Ali, M. 1997. Penelitian Kependidikan Prosedur dan Strategi. Bandung: Angkasa.

Anastasi, Anne and Urbina, Susana. 1997. Psychologycal Testing. New Jersey: Prentice-Hall Inc Published by Simon A Schuster/A Viacom Co Upper Saddle River.
Anderson L.W. 1981. Assesing Affectives Characteritics In The School. Boston: Allyn \& Bacon.

Anthony, J. Nitko, 1996. Educational Assessment of Students. New Jersey: Prentice Hall, Ins Englewood Ciffs.

Barbara, L. Martin and Briggs, Leslie. 1986. The Affectives and Cognitive Domains: Intergration for Instruction and research. New Jersey: Edocational Tecnhology Publications Inc.

Borg \& Gall. 1998. Educational Research. New York: Longman.

Conny Semiawan. 1997. Prespektif Pendidikan Anak Berbakat. Jakarta: Grasindo.

Edward L.1995. Creative Problem Solving. New York: McGraw-Hill, Inc.

Hamalik O. 2002. Pendekatan Guru Berdasarkan Kompetensi. Jakarta: Bumi Aksara.

Jerry Walington. 2006. Educational Research. London: Continum.

Kertias, Sukarno N. dan Hidiat. 1997. Dasar-Dasar Pendidikan Science. Jakarta : Bharata.

Marcelo Alonso and Edward Finn. 1992 Fundamnetal University Phisics, Terjemahan Lea Prasetyo dan Kosnul Hadi. Jakarta : Erlangga. 
Margaret E.Bell Gredler. 1999. Belajar dan Membelajarkan. Jakarta: Radja Grapindo Persada.

Nasution S. 2000. Berbagai Pendekatan dalam Proses Belajar Mengajar. Jakarta: Bumi Aksara.

Norman E. Gronlund and Robert L. Linn. 1990. Measurment and Evaluatioan In Teaching. New York Mcmillan Publishing Company.

Popham. 1992. Classroom Assessment. New York: McGraw-Hill, Inc.
Ratna Willis Dahar. 1989. Teori-Teori Belajar. Jakarta: Erlangga.

Suparno, Paul. 2008. Metodologi Pembelajaran Fisika. Yogyakarta: Kanisius.

Syaodih. N dan Ibrahim. R. 1991. Perencanaan Pengajaran. Jakarta: Rineka Cipta.

Tabrani A. Rusyan. 1989. Pendekatan dalam Proses Belajar Mengajar. Bandung: Remadja Rosdakarya. 